\title{
Penerapan Particle Swarm Optimization pada Metode Neural Network untuk Perawatan Penyakit Kutil melalui Immunotherapy
}

\author{
Esty Purwaningsih ${ }^{\mathrm{a}}$ \\ ${ }^{a}$ Sistem Informasi, Fakultas Teknik dan Informatika, Universitas Bina Sarana Informatika \\ Jl. Kamal Raya No.18, Ringroad Barat, Cengkareng, Jakarta Barat \\ 'esty.epwabsi.ac.id
}

\begin{abstract}
Abstrak
Human papillomaviruses (HPVs) merupakan virus yang menimbulkan infeksi pada permukaan kulit dan dapt menyebabkan tumor sampai dengan kanker, salh satu penyakit yang disebabkan oleh HPVs adalah kutil. Immunotheraphy dapat dimanfaatkan untuk mengobati penyakit kutil. Sehingga penelitian ini melakukan penerapan metode neural network dengan algoritma PSO yang bertujuan untuk mengetahui nilai akurasi dari metode neural network dengan algoritma PSO yang berperan membantu menganalisis apakah peran immunotherapy lebih efektif dalam penyembuhan penyakit kutil. Setelah dilakukan pengujian melalui aplikasi rapid miner diketahui bahwa model Neural Network (NN) dengan algoritma PSO memiliki nilai akurasi sebesar 87.78\%. Hasil perhitungan, performance keakurasian AUC sebesar 0,757 dan memiliki nilai RMSE 0.331. Dengan demikian, metode Neural Network dengan algoritma PSO dapat digunakan untuk perawatan penyakit kutil melalui immunotherapy.
\end{abstract}

Kata kunci: Data Mining, Neural Network, PSO, Immunotherapy

\section{Application of Particle Swarm Optimization in Neural Network Methods for the Treatment of Wart Disease through Immunotherapy}

\begin{abstract}
Human papillomaviruses (HPVs) are viruses that cause infections on the surface of the skin and can cause tumors to cancer, and one disease caused by HPVs is warts. Immunotherapy can be used to treat warts. So, this research applies the neural network method with the PSO algorithm, which aims to determine the accuracy of the neural network method with the PSO algorithm whose role is to help analyze whether the purpose of immunotherapy is more effective in healing warts. After testing through the rapid miner application, it is known that the Neural Network (NN) model with the PSO algorithm has an accuracy value of $87.78 \%$. Calculation results, the AUC accuracy of 0.757 and has an RMSE value of 0.331 . Thus, the Neural Network method with the PSO algorithm can be used for the treatment of warts through immunotherapy.

Keywords: Data Mining, Neural Network, PSO, Immunotherapy

\section{PENDAhuluan}

Human papillomaviruses (HPVs) berupa virus yang menimbulkan infeksi pada permukaan kulit dan dapat menyebabkan tumor [1]. Infeksi dari virus Human Papillomavirus (HPV) ini umumnya dimunculkan dengan adanya kutil [2]. Meskipun kutil dapat tumbuh di semua bagian tubuh manusia seperti lengan, mulut, serta area kelamin, namun kutil paling umum tumbuh di bagian telapak tangan dan kaki [1].

Terdapat berbagai cara dan metode pengobatan untuk menyembuhkan penyakit kutil namun belum ada cara untuk mengetahui penyembuhan mana yang lebih efektif untuk penderita penyakit kutil [3]. Pengobatan seperti cryotherapy dan immunotherapy dapat dimanfaatkan untuk menaklukkan penyakit kutil. Namun, metode

penyembuhan terbaik harus dipilih berdasarkan keadaan pasien. Baru-baru ini, sejumlah teknik machine learning telah berhasil diterapkan pada pemilihan metode perawatan kutil untuk menyembuhkan penyakit kutil [1].

Penelitian ini memilih teknik pengobatan pada penyakit kutil melalui immunotherapy, yang merupakan teknik pengobatan yang bekerja mendorong sistem kekebalan pada tubuh manusia untuk melawan penyakit kutil [2].

Banyak penggunaan metode klasifikasi yang telah dilakukan oleh peneliti-peneliti sebelumnya dalam menyembuhkan dan melalukan perawatan pada kutil yang menghasilkan nilai perolehan yang akurat, misalanya pada metode naive baiyes dan neural network. Salah satunya penelitian [4] untuk perawatan kutil menggunakan metode algoritma k-Nearest Neighbors (KNN) dan Naive Bayes.
\end{abstract}


Penelitian [1] juga dilakukan menggunakan metode pohon klasifikasi dan regresi (CART) untuk memilih perawatan kutil dengan mengembangkan model prediksi akurasi yang mampu menganalisis respons pasien yang mengidap penyakit kutil umum dan/atau plantar terhadap metode cryotherapy dan/atau immunotherapy. Analisis kesalahan mengungkapkan bahwa model CART yang diterapkan memberikan akurasi tertinggi yang dapat dicapai untuk aplikasi yang diminati. Oleh karena itu, model yang diperkenalkan untuk dapat membantu pasien dan dokter untuk menghemat biaya/waktu dan meningkatkan kualitas penyembuhan.

Penelitian [5] memanfaatkan peningkatan optimasi partikel adaptif (IAPSO) untuk membangun sistem berbasis machine learning pada perawatan kutil. [6] membangun sistem pakar untuk membantu pemilihan pengobatan kutil dengan menggunakan metode jaringan saraf fuzzy. Penelitian juga pernah diteliti [7], bahwa untuk memprediksi tingkat keberhasilan metode pengobatan digunakan metode pohon keputusan dengan memberikan interpretasi visual agar mudah dan cepat bagi para ahli medis.

Dari penelitian sebelumnya [8] dikatakan bahwa metode Naive bayes mempunyai tingkat keakurasian lebih baik dari pada metode SVM untuk keberhasilan immunotherapy.

Kegiatan berupa pengumpulan data, pemakaian data yang digunakan untuk menetapkan aturan, struktur dan relasi kedalam big data disebut dengan Data Mining [9] dan merupakan sebuah teknologi yang berguna membantu perusahaan untuk menemukan informasi dari data yang mereka punya. Didalam data mining terdapat beberapa aplikasi yang berfokus pada peramalan yaitu memprediksi suatu kejadian di masa yang akan dating dalam situasi baru dimana data baru berasal dari histori data yang telah terjadi pada waktu sebelumnya [10].

Sistem komputasi yang memiliki karakteristik yang menyerupai jaringan syaraf dan representasi buatan seperti otak manusia yang selalu menstimulasi proses pembelajaran ini dikenal sebagai metode neural network [11]. Neural Network (NN) diyakini terdapat jutaan unit kecil atau sel dan bekerja secara berurutan dengan neuron. Tiap neuron saling berhubungan dengan neuron lainnya melalui suatu koneksi kemudian memproses sebuah inputan serta melampaui output pada satu rangkaian neuron. Dari keluaran yang diregukan oleh tiap neuron akan ditindaklanjuti [12].

Particle Swarm Optimization (PSO) didalam pencarian mempunyai kecepatan dari suatu partikel dan bergerak dengan kecepatan dinamis. Partikel memiliki kencenderungan berjalan menuju area pencarian yang lebih tinggi selama dalam proses pencarian [13]. Particle Swarm Optimization (PSO) telah digunakan sebagai teknik yang efektif di semua bidang termasuk dalam pemilihan fitur [14]. Particle swarm optimization mempunyai keunggulan yaitu untuk memecahkan masalah pada optimasi [15] .

Teknik validasi dilakukan dengan melakukan pembagian data secara random ke dalam $k$ bagian dan proses klasifikasi dilakukan di masing-masing bagian, merupakan teknik dari Cross Validation [16]. Pada pemakaian cross validation dilakukan percobaan sebanyak $k$. Data yang akan dipakai berupa data pelatihan (training-data) yang berguna untuk menemukan angka error keseluruhan. Nilai k dilakukan testing 10 (sepuluh) kali (10-fold cross validation) agar dapat memperkirakan estimasi akurasi. Klasifikasi dapat melakukan pengujian keakuratan dengan menggunakan AUC yang ditetapkan dalam range yaitu nilai Excellent Classification antara 0.90 sampai 1.00, nilai Good Classification antara $0.80-$ 0.90, nilai Fair Classification antara $0.70-0.80$, nilai Poor Classification antara $0.60-0.70$ dan nilai Failure antara $0.50-0.60$ [16].

Pilihan untuk mengambil akar kuadrat MSE disebut Root Mean Squared Error (RMSE). RMSE lebih unaffectedly dari MSE dengan konversi ukur yang sejenis dengan data yang dinilai. Misalnya, dua kali nilai RMSE berarti model mempunyai tingkat error ganda lebih besar dari sebelumnya sedangkan MSE tidak memiliki arti seperti itu. Jika dibandingkan, nilai MSE dikatakan sebagai varian, dan nilai RMSE dikatakan sebagai standar penyimpangan/deviasi [17].

Penelitian ini menerapkan metode klasifikasi neural network dengan algoritma Particle Swarm Optimization (PSO) karena neural network dapat menyelesaikan permasalahan dengan sampel data yang besar dan algoritma Particle Swarm Optimization (PSO) dapat menaikkan bobot pada atribut serta akurasi dari data yang besar. Penelitian ini bertujuan untuk mengetahui nilai akurasi apakah peran immunotherapy lebih efektif dalam penyembuhan penyakit kutil dengan menerapkan metode neural network dengan algoritma PSO.

\section{Metodologi}

Data yang dipakai adalah data immunotherapy, diambil dari Machine Learning Repository UCI immunotherapy. Dalam penelitian ini akan dilakukan beberapa tahapan penelitian seperti gambar 1 di bawah ini:

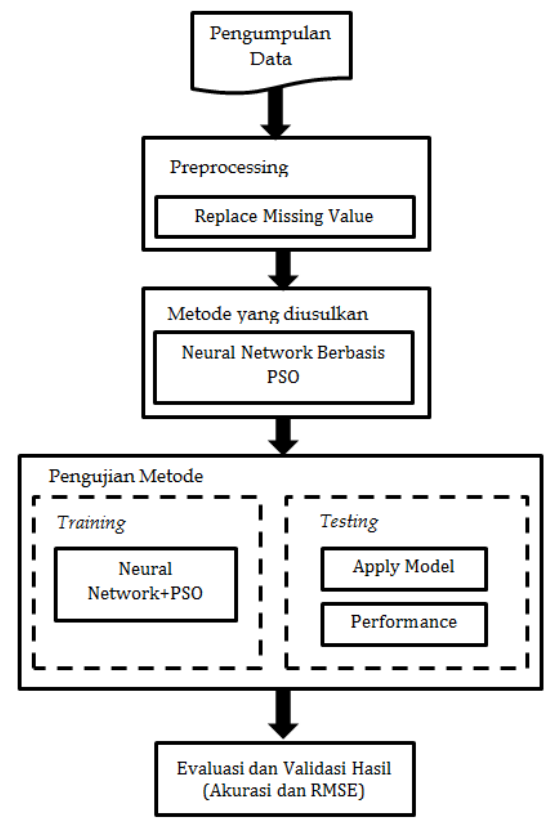

Gambar 1. Metode Penelitian 
1) Pengumpulan Data: Penelitian ini memakai data sekunder dari Machine Learning Repository UCI (klinik dermatologi Rumah Sakit Ghaem di Mashhad mulai Januari 2013 hingga Februari 2015). Kumpulan data dikumpulkan dari pasien, dengan plantar dan kutil umum, yang merujuk ke dermatologi klinik. Data terkumpul sebanyak 90 data dengan 71 pasien dinyatakan berhasil dengan Immunotherapy dan 19 pasien dinyatakan gagal dengan Immunotherapy atribute sex, age, time, number_of_wart, type, area, induration_diameter dan class. Data yang digunakan dapat dilihat pada Tabel. I.

TABEL I

FITUR YANG DIGUNAKAN DALAM METODE IMMUNOTHERAPY

\begin{tabular}{|l|c|c|}
\hline \multicolumn{1}{|c|}{ Atribut } & Nilai & Range \\
\hline class & Yes or No & \\
\hline sex & $\begin{array}{c}41 \text { man } \\
49 \text { woman }\end{array}$ & \\
\hline age & $15-56$ & $31.04 \pm 12.23$ \\
\hline time & $0-12$ & $7.23 \pm 3.10$ \\
\hline number_of_warts & $1-19$ & $6.14 \pm 4.2$ \\
\hline & $\begin{array}{c}\text { 1-common (47) } \\
\text { 2-Plantar (22) } \\
\text { type }\end{array}$ & \\
\hline area & 6-Both (21) & \\
\hline induration_diameter & 5-70 & $95.7 \pm 136.61$ \\
\hline
\end{tabular}

2) Metode yang diusulkan: Metode yang diusulkan untuk mengetahui nilai dari keakurasian data apakah dari data tersebut peran immunotherapy lebih efektif dalam penyembuhan penyakit kutil melalui penerapan metode neural network dengan algoritma PSO dengan menggunakan aplikasi rapid miner 9.0, dari perolehan hasil yang telah diuji akan dijadikan sebagai dasar penentuan perawatan penyakit kutil.

3) Eksperimen dan Pengujian Metode: Data diuji menggunakan metode neural network dengan algoritma PSO yang akan menghasilkan akurasi dalam proses perawatan penyakit kutil. Pengujian menggunakan teknik validation dengan tujuan untuk mendapatkan nilai accuracy. Dataset diuji dengan metode yang diusulkan melalui aplikasi RapidMiner 9.0.

4) Evaluasi dan Validasi Hasil: Setelah tahap pengujian metode diterapkan, hasil uji dari metode neural network dengan algoritma PSO dapat terlihat tingkat nilai akurasi dan nilai AUC (Area Under ROC Curve) sehingga tujuan penerapan metode neural network dengan algoritma PSO untuk menentukan keberhasilan immunotherapy dapat tercapai.

\section{HASIL DAN PEMBAHASAN}

Data didapat dari UCI machine learning repository. Penelitian ini menggunakan metode Neural Network dengan algoritma PSO. Hasil dari penelitian bertujuan untuk mengetahui nilai akurasi apakah peran immunotherapy lebih efektif dalam penyembuhan penyakit kutil dengan menerapkan metode neural network dengan algoritma PSO.

\section{A. Neural Network}

Hasil yang didapat pada gambar 2 dengan metode Neural Network menunjukkan tiga lapisan (layer) yang terdiri lapisan input terdiri dari 7 node diantaranya sex, age, time, number_of_wart, type, area, induration_diameter dan satu node bias. Lapisan yang kedua adalah lapisan tersembunyi (hidden layer) yang terdiri enam node dan satu node bias. Lapisan ketiga adalah output layer terdiri dari dua node yakni atribut kelas yes dan no.

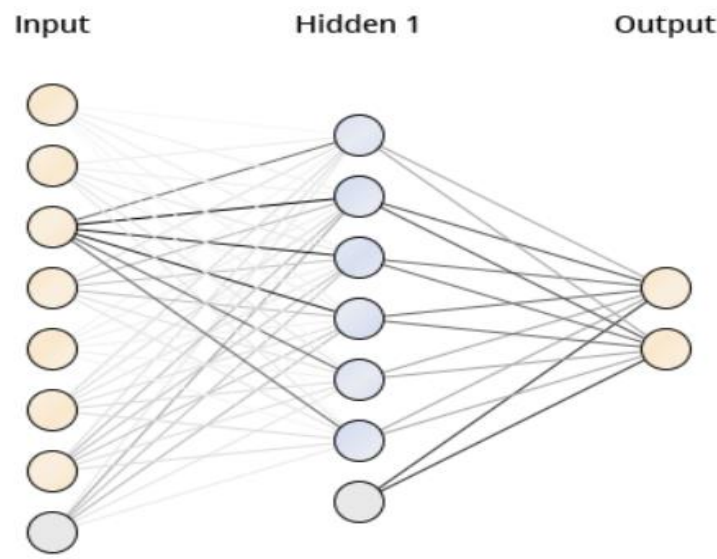

Gambar 2. Neural Net dengan enam simpul pada hidden layer

TABEL II

Nilai AKurasi Data Training Model NeURAl Network

$$
\begin{aligned}
& \begin{array}{|c|c|c|c|}
\hline & \text { True 1 } & \text { True 0 } & \text { Class Precission } \\
\hline \text { Pred. 1 } & 66 & 12 & 83.54 \% \\
\hline \text { Pred. 2 } & 5 & 6 & 54.55 \% \\
\hline \text { Class Recall } & 92.96 \% & 31.58 \% & \\
\hline
\end{array} \\
& \text { Akurasi }=\frac{(\mathrm{TN}+\mathrm{TP})}{(\mathrm{TN}+\mathrm{FN}+\mathrm{TP}+\mathrm{FP})} \times 100 \% \\
& =\frac{(6+66)}{(6+13+66+5)} \times 100 \% \\
& =80.00 \%
\end{aligned}
$$

Pengujian data dengan model Neural Network diperoleh accuracy $80.00 \%$ sesuai pada tabel confusion matrix yang disajikan pada Tabel. 2 dari keseluruhan data 90 record, dinyatakan bahwa 66 data diramalkan masuk klasifikasi class "yes", 13 data diramalkan "yes" namun masuk klasifikasi class "no", 5 data diramalkan "no" tetapi masuk ke klasifikasi "yes" dan 6 data diramalkan masuk klasifikasi "no".

Dari hasil pengolahan dengan menggunakan aplikasi rapid miner diketahui evaluasi nilai ROC untuk model Neural Network dengan menggunakan data training sebesar 0,738 dapat dilihat pada gambar 3. Sedangkan nilai RMSE berjumlah 0.343 . 


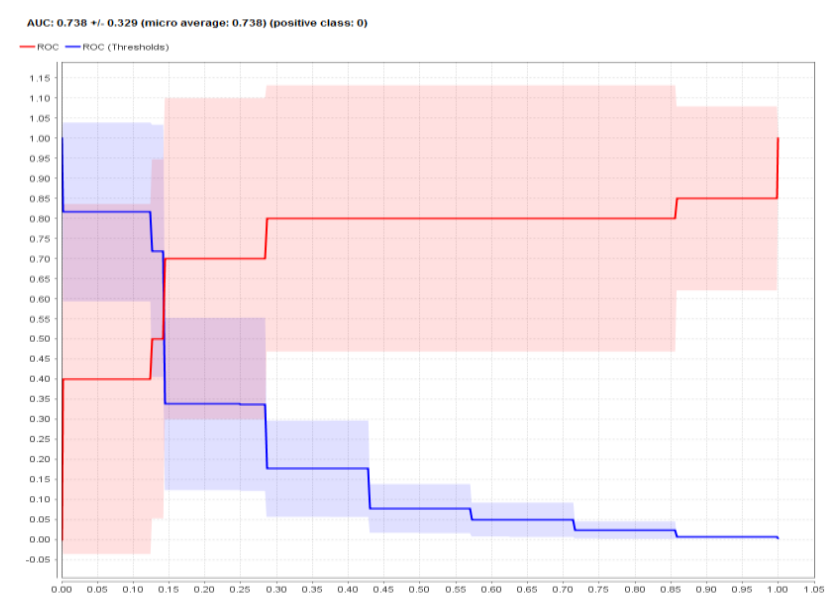

Gambar 3. Kurva AUC Model Neural Network

\section{B. Neural Network + PSO}

Pengujian data dengan model Neural Network diperoleh accuracy $87.78 \%$ sesuai pada tabel confusion matrix yang disajikan pada Tabel. 3 dari 90 record data tertera 68 data diramalkan masuk klasifikasi "yes", 8 data diramalkan "yes" tetapi nyatanya masuk ke klasifikasi "no", 3 data diramalkan "no" tapi masuk klasifikasi "yes", dan 11 data diramalkan masuk ke klasifikasi "no".

TABEL III

Nilai Akurasi Data Training Model Neural Network + PSO

\begin{tabular}{|c|c|c|c|}
\hline & True 1 & True 0 & Class Precission \\
\hline Pred. 1 & 6 & 8 & $89.47 \%$ \\
\hline Pred. 2 & 3 & 11 & $78.57 \%$ \\
\hline Class Recall & $95.77 \%$ & $57.89 \%$ & \\
\hline
\end{tabular}

$$
\begin{aligned}
\text { Akurasi } & =\frac{(\mathrm{TN}+\mathrm{TP})}{(\mathrm{TN}+\mathrm{FN}+\mathrm{TP}+\mathrm{FP})} \times 100 \% \\
& =\frac{(11+68)}{(11+8+68+3)} \times 100 \% \\
& =87.78 \%
\end{aligned}
$$

TABEL IV

OPTIMASI PSO

\begin{tabular}{|c|c|}
\hline Attribute & Weight \\
\hline Sex & 0.561 \\
\hline Age & 0 \\
\hline Time & 0.222 \\
\hline Number of wart & 0.056 \\
\hline Type & 1 \\
\hline Area & 0 \\
\hline Induratio diameter & 0.065 \\
\hline
\end{tabular}

Hasil yang didapat dari pengolahan ROC dengan menggunakan aplikasi rapid miner untuk model Neural Network berbasis PSO diperoleh nilai sebesar 0,757 yang dapat dilihat pada gambar 4, sedangkan nilai RMSE berjumlah 0.331 .

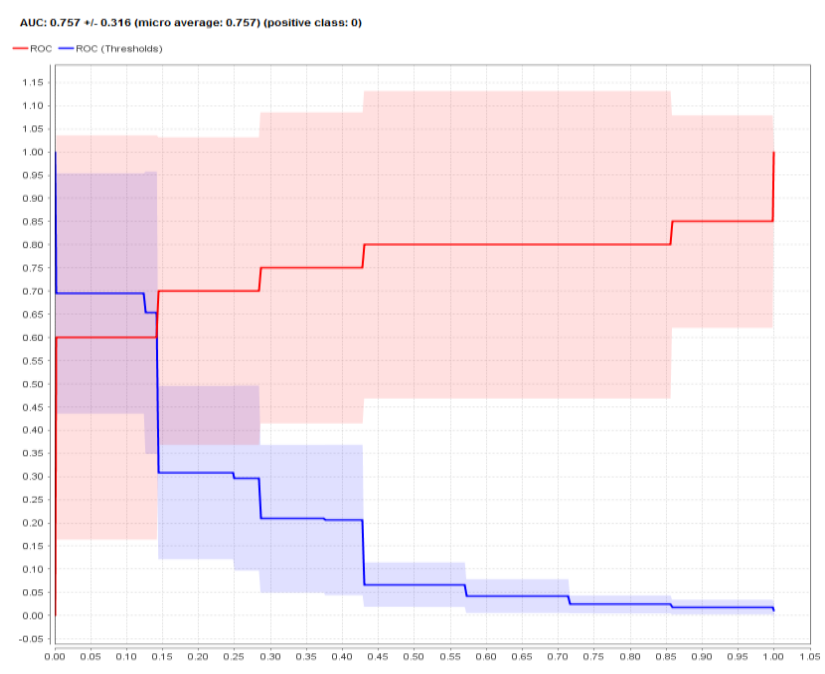

Gambar 4. Kurva AUC Model Neural Network+PSO

\section{KESIMPULAN}

Penelitian ini bertujuan untuk mengetahui nilai akurasi dari perawatan penyakit kutil melalui immunotherapy dengan menerapkan metode neural network berbasis algoritma PSO.

Berdasarkan pengukuran tingkat akurasi melalui aplikasi rapid miner, diketahui bahwa model Neural Network (NN) dengan algoritma PSO memiliki nilai akurasi sebesar $87.78 \%$ lebih besar dari pada akurasi dari metode Neural Network saja yaitu dengan nilai $80.00 \%$. Hasil dari pengolahan data melalui aplikasi rapid miner juga menghasilkan nilai AUC, dimana pada neural network dengan algoritma PSO memiliki nilai lebih tinggi sebesar 0,757 dan memiliki nilai Root Mean Squared Error (RMSE) lebih rendah sebesar 0.331 dibanding dengan nilai AUC pada metode neural network sebesar 0.738 dan nilai RMSE 0.343 .

Jika ditarik kesimpulan, metode Neural Network dengan algoritma PSO memiliki accuracy lebih unggul dari metode Neural Network dimana telah dilakukan juga oleh peneliti-peneliti sebelumnya yang menggunakan metode neural network, SVM dan Nä̈ve Bayes dengan kasus yang sama yaitu tentang perawatan kutil.

Pada penelitian ini dilakukan dengan menggunakan algoritma PSO, dimana mempunyai keunggulan bahwa algoritma tersebut dapat meningkatkan tingkat akurasi. Dengan demikian, metode Neural Network dengan algoritma PSO dapat digunakan untuk perawatan penyakit kutil melalui immunotherapy.

\section{DAFTAR PUSTAKA}

[1] M. M. Ghiasi and S. Zendehboudi, "Decision tree-based methodology to select a proper approach for wart treatment," Comput. Biol. Med., vol. 108, no. February, pp. 400-409, 2019. F. Khozeimeh et al., "Intralesional immunotherapy compared to cryotherapy in the treatment of warts," Int. J. Dermatol., vol. 56, no. 4, pp. 474-478, 2017.

[3] W. Jia, H. Xia, L. Jia, Y. Deng, and X. Liu, "The selection of wart treatment method based on Synthetic Minority Oversampling Technique and Axiomatic Fuzzy Set theory," Biocybern. Biomed. Eng., pp. 1-10, 2020.

[4] I. Medikal, E. Üniversitesi, and E. Binası, "Naive Bayes ve En Yakın k Kom , su Sınıflandırıcıları ile Si - gil Tedavi Yöntemi Seçimi Choose of Wart Treatment Method Using Naive Bayes 
and k-Nearest Neighbors Classifiers," pp. 0-3, 2018.

[5] M. Abdar et al., IAPSO-AIRS: A novel improved machine learning-based system for wart disease treatment, vol. 43, no. 7. 2019.

[6] A. Junio Guimarães, P. Vitor de Campos Souza, V. Jonathan Silva Araújo, T. Silva Rezende, and V. Souza Araújo, "Pruning Fuzzy Neural Network Applied to the Construction of Expert Systems to Aid in the Diagnosis of the Treatment of Cryotherapy and Immunotherapy," Big Data Cogn. Comput., vol. 3, no. 2, p. 22, 2019.

[7] S. B. Akben, "Predicting the success of wart treatment methods using decision tree based fuzzy informative images," Biocybern. Biomed. Eng., vol. 38, no. 4, pp. 819-827, 2018.

[8] A. Supriyatna and W. P. Mustika, "Komparasi Algoritma Naive bayes dan SVM Untuk Memprediksi Keberhasilan Imunoterapi Pada Penyakit Kutil," J-SAKTI (Jurnal Sain Komput. dan Inform., vol. 2, no. 2, p. 152, 2018.

[9] B. Santosa, Data Mining: Teknik Pemanfaatan Data Untuk Keperluan Bisnis. Yogyakarta: Graha Ilmu, 2007.

[10] M. A. Witten, I. H., Frank, E., \& Hall, Data Mining : Practical Machine Learning and Tools. Burlington: Morgan Kaufmann Publisher, 2011.

[11] A. E, Pengantar Jaringan Saraf Tiruan. Wonosobo: Star Publishing, 2009

[12] K. A, Shukla; R, Tiwari;R, Real Life Application of Soft Computing. CRC Press, 2010

[13] H. Muhamad, C. A. Prasojo, N. A. Sugianto, L. Surtiningsih, and I. Cholissodin, "Optimasi Naïve Bayes Classifier Dengan Menggunakan Particle Swarm Optimization Pada Data Iris," J. Teknol. Inf. dan Ilmu Komput., vol. 4, no. 3, p. 180, 2017.

[14] B. Xue, M. Zhang, S. Member, and W. N. Browne, "Particle Swarm Optimization for Feature Selection in Classification : A Multi-Objective Approach," Ieee Trans. Cybern., pp. 1-16, 2012.

[15] Ridwansyah, I. Ariyati, and S. Faizah, "Particle Swarm Optimization Berbasis Co-Evolusioner," J. SAINTEKOM, vol. 9, no. 2, pp. 166-177, 2012.

[16] F. Gorunescu, Data Mining Concepts, Models and Techniques. Berlin Heidelberg: Springer Verlag, 2011.

[17] S. S, Metode Peramalan Bisnis Masa Kini dengan Minitab dan SPSS. Jakarta: PT Elex Media Komputindo, 2009. 